\title{
DEVELOPMENT OF ECOLOGICAL CULTURE IN STUDENTS DURING PHYSICAL EDUCATION CLASSES
}

\author{
Mukhammadiev K.B. \\ Doctor Of Philosophy In Pedagogical Sciences, Tashkent State Transport University Uzbekistan
}

\section{ABSTRACT}

Environmental problems in the world today remain one of the most pressing, global issues that need to be addressed through fundamental, pedagogical research and scientific research.

KEYWORDS:- Physical culture, pedagogy, education, nature, teaching, development.

\section{INTRODUCTION}

As science and technology advance, global environmental problems arise as a result of mismanagement of the environment, threatening human life to varying degrees. Ecology has now become one of the international disciplines and is tasked with addressing the relationship between the environment and man (demography, food shortages, climate change, the "greenhouse effect", the depletion of the ozone layer, energy shortages, waste, air pollution and water pollution, land desertification and salinization) [14].

One of the most pressing pedagogical problems is the development of ecological culture in students, the development of ecological culture in the process of physical education. Because it is the future specialists-educators who must fulfill such an important task as raising the ecological culture of young people to a high level of quality and educating mature people who can contribute to the protection of nature.

Today, global environmental information disseminated through the media is seen as a process of continuous education, which is combined with common tasks and systematized in connection with the training of specialists.

Methods. Analysis of scientific and methodological literature, pedagogical observation and analysis, historical comparative analysis

Results and Discussion. As a result of educating students about the environment, their ecological culture is formed. This process is carried out in two stages:

In the first stage - by equipping students with knowledge about the environment, they form an understanding, imagination, attitude about the environment, and environmental activity occurs.

In the second stage - in the process of learning 
CURRENT RESEARCH JOURNAL OF PEDAGOGICS 2(10): 163-174,

October 2021 DOI: https://doi.org/10.37547/pedagogics-crjp-02-10-30

ISSN 2767-3278

(C)2021 Master Journals

\section{Crossref do: 81 Google}

Accepted $26^{\text {th }}$ October, 2021 \& Published $31^{\text {th }}$ October, 2021

about the environment, students develop a stable ecological relationship with the environment, their thinking grows and their worldview develops.

These ideas are evident in the activities that students carry out in relation to the environment. As a result, these stages together and in an interconnected way lead to the formation of an ecological culture in the student

If it is assumed that man is in regular interaction with nature, the necessary laws of this relationship should form the basis of the educational system [18].

The goal of environmental education is to develop a system of knowledge, skills, competencies, attitudes, and beliefs that allow students to respond responsibly to the environment.

The implementation of the above steps in an integrated manner leads to the full development of environmental culture in students during physical education classes (see Figure 1).

\section{Figure 1}

\section{Model of the mechanism of development of ecological culture in students in the process of physical education}

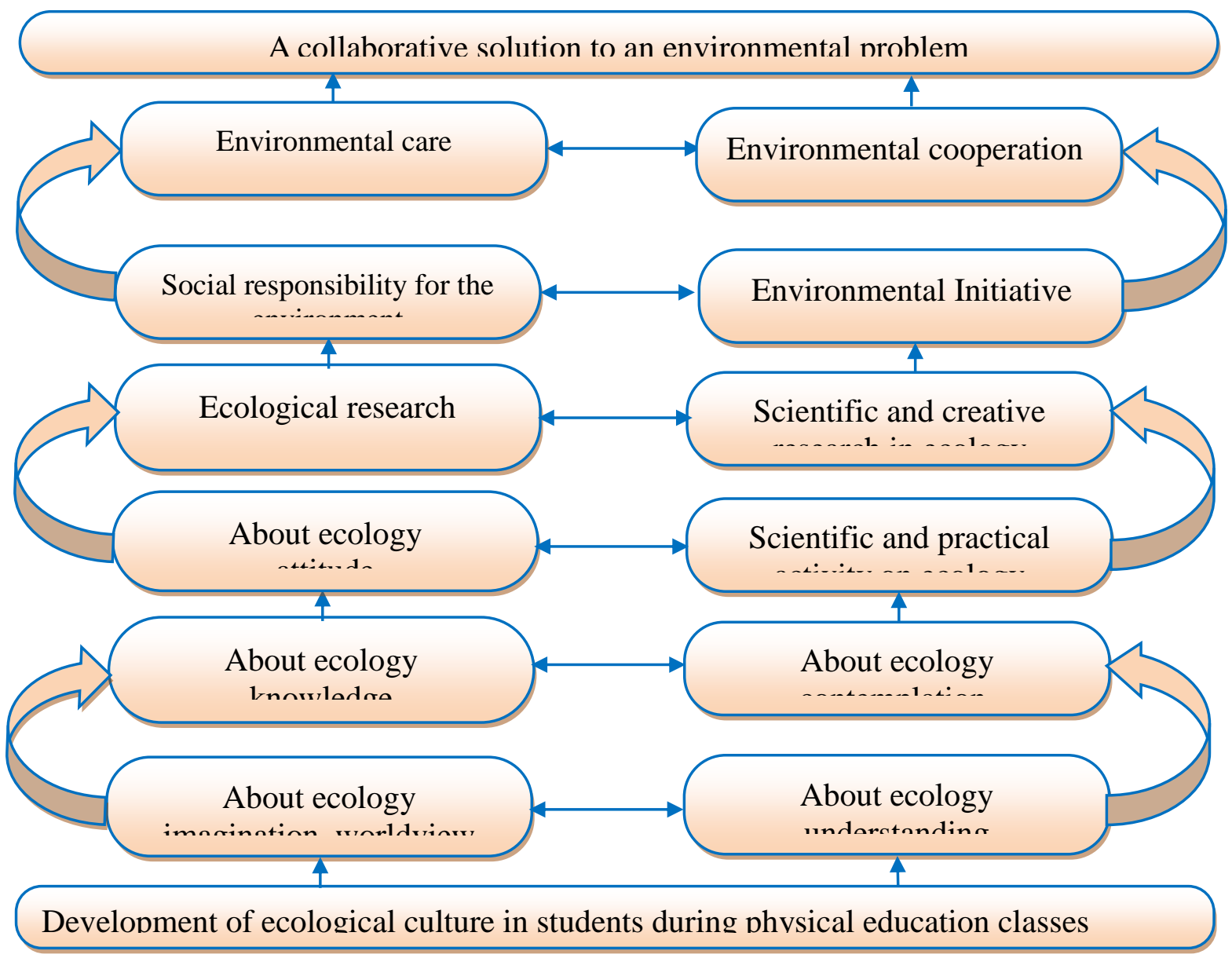


Eco-culture encompasses the development of students' sense of responsibility for a conscious attitude to the environment as a national and universal value, the ability to solve problems scientifically and practically.

Natural and anthropogenic problems on the planet, including in the territory of our republic, make the main task of the system of continuous education the scientific and practical solution of the following urgent problems:

development of ecological culture in students in the process of physical education, the formation and strengthening of a sense of integrity and interconnectedness of the components of nature;

to ensure that students in the process of physical education as a means of determining the ecological culture;

understanding that physical education is a key factor in the development of students' universal culture in the classroom;

scientifically and practically clearly define the goals and objectives of the development of ecological culture in students in the process of physical education, to understand its practical orientation;

approach to the development of environmental culture in students as a historical, national, universal, social problem in the process of physical education;

to achieve didactic support of the educational system aimed at the development of ecological culture in students in the process of physical education [17].

In order to achieve this, it is necessary to scientifically, practically, pedagogically and methodically determine the content of educational materials on the development of ecological culture in students during physical education classes, to inculcate in students the types of activities related to environmental protection, to anticipate events in human nature and the environment. , they need to understand that their naturalness, perfection, understanding, and a conscious attitude towards the environment are a priority. In this regard, the definition of the content of the development of environmental culture in students in the process of physical education is an important pedagogical problem.

The content of environmental knowledge that students need to know must meet the following criteria:

the emergence of the universe, the continuous and integral integrity of its development;

development of the natural landscape in the minds of students;

scientific and practical inculcation in the minds of students the essence of knowledge about the laws between nature and society;

by students of the method (law - 1. Relationships between objective phenomena and their laws. Objective laws. Laws of development of society. 2. On a legal basis, naturally occurring, natural, inevitable action, event, etc.) [17]. to achieve mastery;

understanding of natural, anthropogenic phenomena occurring in nature and the tragedies that occur as a result of them; to know their essence, to express environmental educational tasks, to plan and implement observations and experiments, to clarify theoretical and practical ideas on the development of ecological culture in students in the process of physical education, to use them in the educational process;

to instill in students a sense of respect for the environment and the development of environmental culture;

improving skills and competencies in environmental protection and efficient use of 
CURRENT RESEARCH JOURNAL OF PEDAGOGICS 2(10): 163-174,

October 2021 DOI: https://doi.org/10.37547/pedagogics-crjp-02-10-30

ISSN 2767-3278

(C)2021 Master Journals

\section{Crossref doi) g/ Google}

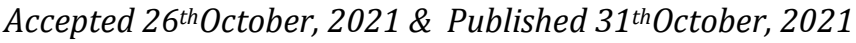

natural resources;

preparing students for protection from any natural, anthropogenic events;

scientific-practical, pedagogical, methodological development of the scope of development, definition, systematization, development of imagination and concepts in students in the field of development of ecological culture in students in the process of physical education;

preparing students for environmental protection;

to teach students the optimal methods aimed at the efficient use of natural resources;

setting environmental standards for students in relation to the environment;

to form in students an ecological attitude that has a positive impact on the environment;

to teach students to save time and use it effectively.

Ecology, in its essence, scientifically and practically determines the nature of the various interactions of humanity with nature and its objects [14].

The content of education in the development of ecological culture in students in the process of physical education reflects the knowledge of natural, concrete, social, political sciences. At the same time, all disciplines incorporate the idea of developing a general ecological culture into their content, arousing students' interest in learning the basics of the natural sciences, allowing them to consciously master the laws of ecology. The integrated state of these forms a universal ecological culture in students.

Accordingly, environmental education is multifaceted, and in the process of physical education classes, the organization of lectures for the development of environmental culture in students according to their specialization gives good results. These ideas are comprehensive and take a long time and effort to solve. Although in part, we have solved this problem. As an example, we have focused on the areas of ecology and the environment related to physical education.

The content of the problem we want to solve meets the following requirements: sports, fitness, self-protection and environmental protection. The basic environmental knowledge that students need to know is:

awareness of the need to develop environmental culture in students during physical education classes;

be able to anticipate the environmental consequences of their activities;

to be able to work in the heart of nature and feel that it is a national value, a wealth;

relying on natural-scientific, geological, geographical, demographic, technical and humanitarian knowledge in drawing conclusions about the relationship with ecology;

to rely on national, local, historical development, universal values when dealing with nature.

They form the basis of the content of general environmental education that students need to know and solve problems in the following areas:

development of students' scientific, national, universal views on nature and ecology;

understanding the interrelationships of nature, technology and society and the anthropogeological relationships between them;

achieving direct geo-ecological harmony in solving problems of nature-human-technical relations;

Students should have the following skills for the development of environmental culture in the process of physical education:

scientific and practical understanding of the 
causes of environmental problems;

to have a culture of understanding and protection from natural and anthropogenic emergencies and their negative consequences;

to know, analyze and draw conclusions from accurate data on the use of natural resources;

to carry out simple research work on environmental ecology, analyze the results, draw conclusions, make decisions;

scientific and practical study of local, regional, global environmental problems; to be able to analyze the obtained results and be active in overcoming shortcomings, to draw conclusions [17].

Students must master an environmental culture in all situations.

The abundance of natural-scientific, psychological, educational and pedagogical factors in the studied problems creates the need for a continuous and integrated approach in the development of students' culture of ecology and environmental awareness.

The following principles were used in the selection of materials for the development of environmental culture in students in the process of physical education:

Methodological principles:

recognition of nature as an ecological value, a pillar of the social environment;

understanding that man, as an integral part of nature, is a factor capable of altering natural and social development;

to feel that the history of mankind is an integral part of the history of nature;

anthropogenic impact on nature and recognition and adherence to its consequences;

understanding that human health depends on the ecological state; to know the impact of technical progress on the environment and to protect against its negative consequences.

The interdependence and interdependence of environmental concepts is reflected in the following:

knowledge of the laws of interaction of nature and society;

that all human activities are directly related to the environment;

to determine the theoretical and practical aspects of the use of nature in the development of ecological culture in students;

Living in harmony with it without adversely affecting the environment, promoting its development.

The interoperability of environmental components requires:

development of the idea of the integrity of environmental problems;

use of ecological education in all means of education;

ensuring the continuity and continuity of environmental knowledge in student activities;

ensuring harmony in the development of students' environmental awareness.

Interdisciplinary relevance in the selection of materials for the study of ecology requires:

disclosure of the content of environmental knowledge in each subject;

development of the integrated content of environmental education as an educational value and with the help of activities;

disclosure of specific features of each subject, ensuring the interconnectedness of disciplines, coordination, ie the implementation of interdisciplinary integration; 
CURRENT RESEARCH JOURNAL OF PEDAGOGICS 2(10): 163-174,

October 2021 DOI: https://doi.org/10.37547/pedagogics-crjp-02-10-30

ISSN 2767-3278

(C)2021 Master Journals

\section{Crossref doi) 81 Google}

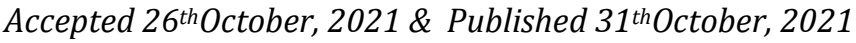

Ensuring the implementation of aspects related to the professional and environmental training of students in the interdisciplinary approach [17].

Unit of theory and practice:

achieving natural balance on the basis of existing laws of nature;

norms and rules of attitude to nature need to be taken into account in the unity of educational and practical activities related to the protection of the environment [17].

The research was conducted on the basis of the above principles of scientificity, consistency, systematicity, continuity, continuity, demonstration, comprehensibility, awareness, activism. Based on these principles, attention will be paid to the following activities:

educational activity - focuses on the content of environmental knowledge, methodological ideas about the relationship between nature and society, which excludes a one-sided approach to nature based only on consumption, as well as the norms and laws of a conscious attitude to the environment from a legal and scientific point of view;

practical activity - the complex content of the development of environmental culture is mastered by students in sequence at all stages of the educational process.

The types of practical activities for the development of environmental culture in students in the process of physical education are:

a) identify and systematize the content of knowledge related to the development of environmental culture, which forms the basis of the content of general education that students need to know;

b) integration of emotional, valuable relationships (related to environmental education, efficient use of natural resources) and creative activities in the implementation of education in the development of environmental culture in students during physical education classes.

The process of ecological education in practical activities is a factor that leads to the fulfillment of a specific goal in the psychological, pedagogical, motivated human activity, vaj; (r. <fr. - a structural element of the plot, the main content, theme of the work) comprehensively includes such components as process, evaluative, artisticcreative, practical activity [17].

When studying the content of the activities of higher education institutions in theory and practice, it was observed that in the process of physical education, opportunities for the development of environmental culture of students are not used effectively. To implement them, it is necessary to systematically plan activities for the development of environmental culture in students.

The main reasons for the low level of knowledge of students about the development of ecological culture in the process of physical education - the lack of ideas about the development of ecological culture in the content of the curriculum, textbooks, manuals and recommendations; teachers do not fully understand the relevant issues, the essence of communication with the environment and do not have experience in promoting environmental culture among students; public organizations, the lack of support from the media in this regard (inadvertently) is explained by the lack of certain conditions [17].

As a result of scientific and practical research, it was found that the reasons for the low level of understanding of the essence of the development of environmental culture by students in the process of physical education are as follows:

Insufficient resources for the development of ecological culture in students and its content in 
CURRENT RESEARCH JOURNAL OF PEDAGOGICS 2(10): 163-174,

October 2021 DOI: https://doi.org/10.37547/pedagogics-crjp-02-10-30

ISSN 2767-3278

(C)2021 Master Journals

\section{Crossref doi) 81 Google}

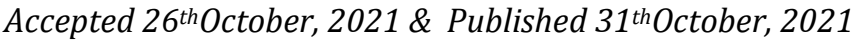

the process of physical education;

the essence of the development of ecological culture of the population in the media is onesided coverage or insufficient coverage;

incomplete reflection of the concepts of development of ecological culture in students in the content of educational disciplines in the course of physical training;

science teachers are not fully aware of the importance of developing environmental culture and rational use of natural resources;

lack of attention to the promotion of the idea of developing environmental culture in students in the teaching of subjects, including physical education;

shallowness of the content of measures for the development of ecological culture and their inconsistency and systematic organization with a specific goal;

lack of effective forms, methods and tools in the organization of propaganda of the idea of development of ecological culture in pedagogical processes;

unsatisfactory need and interest in learning, mastering the knowledge, skills and abilities of students in the development of environmental culture;

lack of strong cooperation between organizations, communities, families in the process of developing ecological culture and organizing the promotion of the idea of using natural resources;

Insufficient attention is paid to this area in higher education institutions, institutes for retraining and advanced training of teachers [17].

The analysis showed that the students involved in the experimental and control groups did not fully master the idea of developing an environmental culture. This is due to the fact that the ideas of developing an environmental culture are not promoted among students in the educational process.

Our research has shown that the program, scientific-methodical manual and recommendations for the development of environmental culture for students are not sufficiently developed. For this reason, teachers face difficulties in developing an environmental culture in students. This negatively affects the development of environmental culture in the future specialist [17].

Therefore, for the proper use of science and technology and its achievements, and for the development of ecological culture, it is necessary to organize educational work on the elimination of problems in this area and the purposeful development of ecological culture of the younger generation.

The development of ecological culture in students should be carried out in a systematic, conscious, effective, compatible with theoretical and practical, national, regional and universal, interdisciplinary.

Problems related to the development of ecological culture can be studied in research, taking into account the following:

that the development of ecological culture is a universal problem;

adherence to historical, national, local, universal values;

measures for the conscious use and restoration of natural resources;

effective use of the positive achievements of modern science and technology.

The main purpose of educating students is to form in them a conscious attitude to the place where they live, its natural resources, flora and fauna. 
CURRENT RESEARCH JOURNAL OF PEDAGOGICS 2(10): 163-174,

October 2021 DOI: https://doi.org/10.37547/pedagogics-crjp-02-10-30

ISSN 2767-3278

(C)2021 Master Journals

\section{Crossref doi) 81 Google}

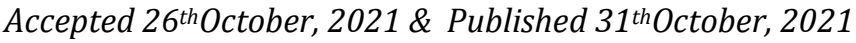

In developing the ecological culture of students should pay attention to the following:

taking into account the economic, political, cultural and historical, aesthetic, hygienic, health-oriented areas of environmental education;

ensuring continuity and continuity in all stages of education aimed at the development of environmental culture in students in the classroom and in the process of extracurricular education;

to have an interdisciplinary systematic approach, to rely on the exact content of the subject, not to take too much time;

to be able to analyze the main issues of ecological culture development in terms of local, regional and global levels;

to pay attention to the past, present and future state of ecological culture, taking into account the historical;

be able to analyze scientifically and practically, understanding the importance and necessity of local, national and international cooperation in solving environmental problems between ecology and man;

to develop students' ability to understand ecology as a value;

to develop ecological culture in students in the process of physical education classes with the widespread use of new pedagogical technologies in the study of the subject and out-of-class educational work [17].

The data show that raising the environmental awareness of students through the development of environmental culture in the process of physical education is an extremely important and global challenge. Because environmental education covers all disciplines and at the same time all disciplines work based on ecology. This means that each science itself is linked to ecology. Therefore, the theory of environmental education consists of two types, namely "shell" and "core". While it is mandatory for all students to study the "core" of the theory of environmental education, the "shell" of the theory is studied taking into account the specifics of the subject.

Accordingly, in the process of physical education in the development of environmental culture in students should take into account the following:

the general preparation of students is a methodological basis and requires the study of academic disciplines on the basis of professional orientation. It includes the general laws of the interaction of nature and society, social mechanisms of scientific management of ecology and social relations, environmental problems and their essence;

In the scientific training of students, the ways to solve environmental problems in the areas of specialization are clearly indicated [17].

The greening of the fields of physical education, their content includes a systematic approach.

Another important task of physical education is to deepen the knowledge, skills and abilities of students in a particular sport, which is associated with the development of environmental culture in the process of physical education.

The eco-content of physical education and sports for students should be determined on the basis of the following four areas:

maintaining and protecting the health of students;

development of ecological culture and ensuring that students follow the rules of a healthy lifestyle during physical education classes;

to ensure that they follow the rules of the sport during the organization and conduct of mobile games, eco-marathons, eco-travels, sports games, to beware of unforeseen, accidental incidents 
CURRENT RESEARCH JOURNAL OF PEDAGOGICS 2(10): 163-174,

October 2021 DOI: https://doi.org/10.37547/pedagogics-crjp-02-10-30

ISSN 2767-3278

(C)2021 Master Journals

\section{Crossref doi 81 Google}

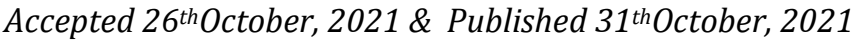

during the games.

Factors and methods of developing ecological culture in students during physical education:

scientific factor - the problem of developing ecological culture in students in the process of physical education is not sufficiently covered in scientific and theoretical terms;

social factor - the activities of society, educational institutions, communities in the development of ecological culture in students in the process of physical education have different directions, ecological views are not focused on one goal, actions to solve existing problems are different, ie they are not scientifically perfect, not systematized carried out without;

scientific-methodical factor - the problem of developing ecological culture in students in the process of physical education at all levels of the system of continuing education is recognized as an integral part of the educational process, its content is scientifically-methodologically defined, defined, the system of teaching methods is not created [17].

Ecological knowledge, skills and competencies related to the development of ecological culture in students during physical education classes are not scientifically and practically related to the profession, field of activity of future specialists and environmental problems in the relevant areas (see Figure 2-3).

\section{2-3 drawings.}

\section{Model of development of ecological culture in students in the process of physical education}

\begin{tabular}{|c|c|c|c|}
\hline \multicolumn{4}{|c|}{ Development of ecological culture in students during physical education classes } \\
\hline \multicolumn{4}{|c|}{$\begin{array}{l}\text { Purpose: to create scientific recommendations aimed at the development of } \\
\text { envirnnmental multure in students in the nrosece of nhvsical eduration }\end{array}$} \\
\hline$\frac{1}{t}$ & $\bar{t}$ & $\downarrow$ & $\nabla$ \\
\hline$\downarrow$ & $\mp$ & $\downarrow$ & 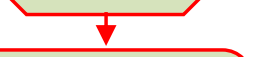 \\
\hline \multicolumn{4}{|c|}{ Functional functions } \\
\hline$\frac{1}{t}$ & $\frac{1}{1}$ & 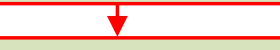 & $\frac{1}{t}$ \\
\hline $\begin{array}{l}\text { Development of scientific and } \\
\text { methodologicalrecommendat-ions } \\
\text { aimed at improving the cur-rent } \\
\text { situation, historical deve-lopment, } \\
\text { pedagogical aspects, model of the } \\
\text { pedagogical sys-tem, didactic } \\
\text { principles, identify-cation of } \\
\text { effective forms, methods and tools }\end{array}$ & $\begin{array}{l}\text { Improving the sys-tem } \\
\text { of develop-ment of } \\
\text { ecological culture in } \\
\text { students and enriching } \\
\text { it with scientific and } \\
\text { methodological } \\
\text { recommendations in } \\
\text { the process of physical } \\
\text { education }\end{array}$ & $\begin{array}{l}\text { Pedagogical } \\
\text { observation, } \\
\text { questionnaires, } \\
\text { interviews, inter- } \\
\text { active, } \\
\text { pedagogical } \\
\text { experiments, } \\
\text { mathematical- } \\
\text { statistical methods }\end{array}$ & $\begin{array}{l}\text { Development of } \\
\text { conclusions and } \\
\text { recommen- } \\
\text { dations based on } \\
\text { the analysis and } \\
\text { results of } \\
\text { scientific and } \\
\text { pedagogical } \\
\text { research }\end{array}$ \\
\hline
\end{tabular}


CURRENT RESEARCH JOURNAL OF PEDAGOGICS 2(10): 163-174,

October 2021 DOI: https://doi.org/10.37547/pedagogics-crjp-02-10-30

ISSN 2767-3278

(C)2021 Master Journals

\section{Crossref do) 81 Google}

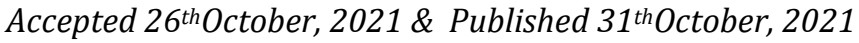

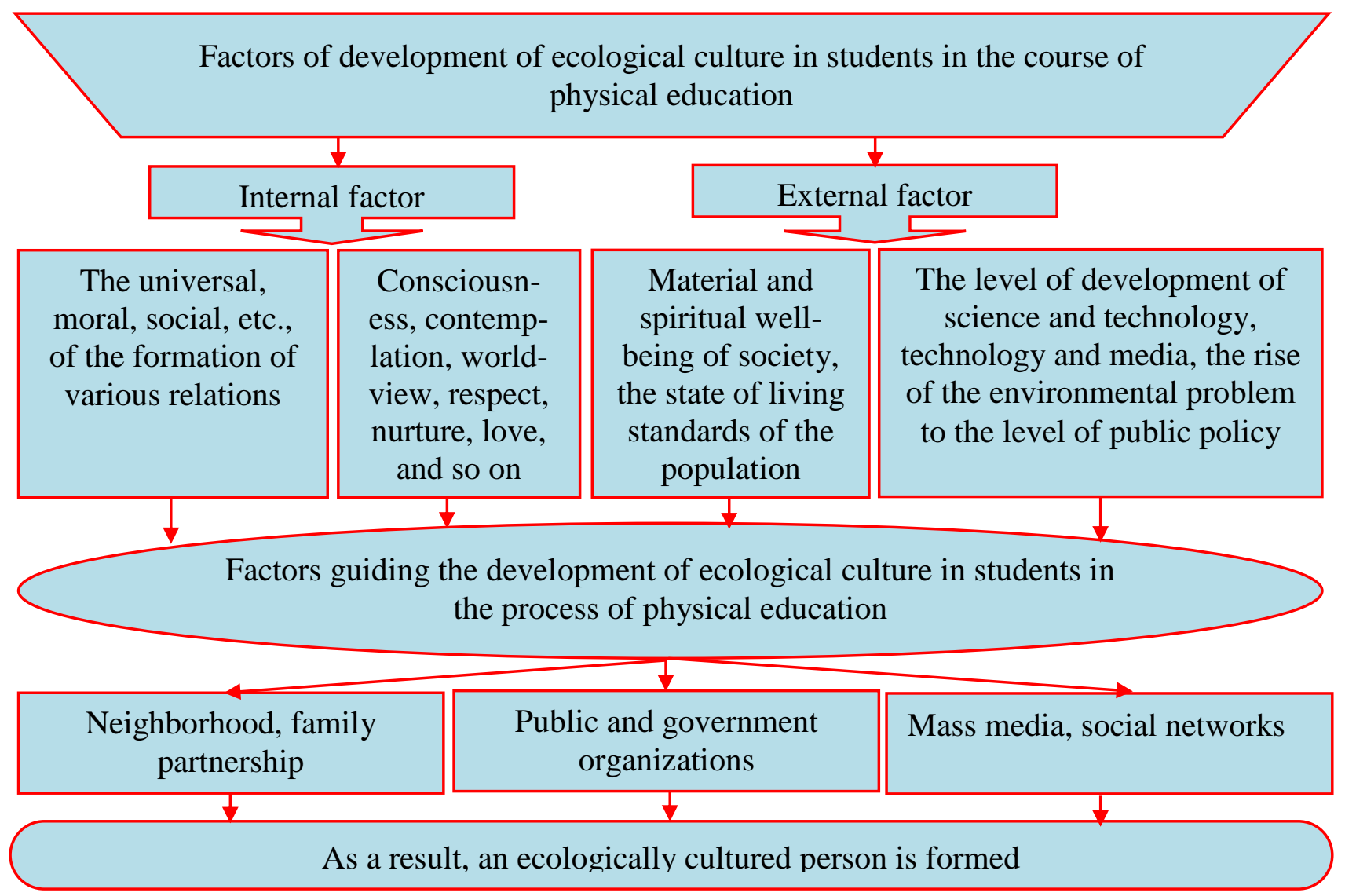

\section{Conclusions}

In summary, although the tasks set out in the Concept of Continuing Environmental Education have found practical application in the field of education, the inculcation of environmental knowledge in the content of physical education subjects aimed at developing environmental culture in students during physical education has not been done on a scientific basis [17].

In solving these problems, we have developed a model for the development of environmental culture in students in the process of physical education.

\section{REFERENCES}

1. Valukonis G.Yu., Muradov Sh.O. Basics of ecology. Volume I. General ecology. Kn.1 Tashkent: "Mehnat", 2001. - 328 p.

2. Jirinkov G.A. and dr. Protected environment in Uzbekistan. - Tashkent: 1993.- 103 p.

3. Zverev I.D. Postulates of development of ecological culture / Ecological culture of education: theses of dokl.sessii of the Scientific Council on problems of ecological education RAO // Under ed. L.P.Semenovoy and S.N.Glazachev. 
CURRENT RESEARCH JOURNAL OF PEDAGOGICS 2(10): 163-174,

October 2021 DOI: https://doi.org/10.37547/pedagogics-crjp-02-10-30

ISSN 2767-3278

(C)2021 Master Journals

\section{Crossref do) 81 Google}

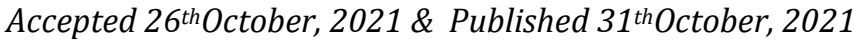

Moscow: 1998. - P.14 - 16.

4. Ziyomuhammedov B. Ecology and spirituality. - Tashkent: "Mehnat", 1997. $104 \mathrm{p}$.

5. Karimov Yu. Theoretical bases of ecological education of university students (on the example of teaching general technical sciences to university students). Tashkent: “Fan”, 1995. - 118 p.

6. Muxammadiev K.B. The role of excursions in the development of ecological culture in the system of continuing education // Continuing education. Scientificmethodical journal. - Tashkent: 2012. Issue 5. - P. 62-66.

7. Muxammadiev K.B. Eco-hygienic aspects of the development of physical education in students // Teacher and continuous education. - Nukus: 2013. - Issue 5. - P. 25-28.

8. 3. Mukhammadiev K.B. The use of distance learning methods in the formation of students' respect for the environment // Actual problems of modern science. Materials of the XII International Scientific and Practical Conference. - Moscow: 2013. - P. 93-96.

9. Muxammadiev K.B. Theory and practice of preparing students to be environmentally friendly / textbook. - Tashkent: "Science and technology", 2014. - 170 p.

10. Muxammadiev K.B. Ecovaleological possibilities of preparing students for environmental awareness / methodical manual. - Tashkent: "Science and technology", 2014. - 199 p.

11. Muxammadiev K.B. The level of effectiveness of preparing students for environmental awareness in the process of physical education. - Tashkent: "Fan- sportga". Scientific-theoretical journal. 2015. - Issue 2. - P. 31-36.

12. Mukhammadiev K.B. Formation of general cultural attitudes towards the environment among students as a factor in the development of a healthy lifestyle. "Science and World" Monthly scientific journal. Volgograd: No. 2 (18) 2015. - P. 126 - 129.

13. Muxammadiyev К.Б. Creating general cultural attitude towards the environment student as a factor in the evelopment of healthi lifestayle. Germaniya №1. 2015. European applied Sciences. P. 51-53.

14. Muxammadiev K.B. Theories of preparing students to be careful with the environment / Monograph. - Tashkent: "Science and technology", 2016. - 202 p.

15. Mukhammadiev K.B. Environmental opportunities while respecting the environment of students. - Cheboksary: 2017. - P. 570-573.

16. Muhammadiev KB, Turdikulov E. Methods of protecting the population from environmental emergencies. // Collection of scientific seminar-exhibition materials. Tashkent: 2017. - P. 61-63.

17. Muxammadiev K.B. To develop students attentive attitude to the environment in the process of physical education. Dis ... Ph.D. in Ph.D. (PhD). - Chirchiq: 2018. $137 \mathrm{p}$.

18. Mukhammadiev K.B. Theoretical foundations and pedagogical system for the development of a careful attitude of students to the environment in the educational process of physical education // Actual problems of physical culture and sports in modern economic conditions. Materials of the International Scientific and Practical Conference - Cheboksay: May 20, 
CURRENT RESEARCH JOURNAL OF PEDAGOGICS 2(10): 163-174,

October 2021 DOI: https://doi.org/10.37547/pedagogics-crjp-02-10-30

ISSN 2767-3278

(C)2021 Master Journals

Crossref doi) 81 Google

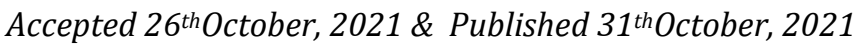

2019. - P. 161-165.

19. Muxammadiev K.B. The content, pedagogical possibilities and selection principles of the development of students' careful attitude to the environment in the process of physical education // Trends and prospects for the development of science and education in the context of globalization. Materials of the International Scientific and Practical Internet Conference - Pereyaslav-Khmelnitsky: May 31, 2019. P. 461-463.

20. Mukhammadiev K.B. Theoretical foundations and pedagogical system for the development of a careful attitude of students to the environment in the educational process of physical education // Science and world. Volgograd- II .: No. 11 (75). Science and the world // International scientific journal, no. 11 (75). - Volgograd. 2019.Vol. 2. - P. 33-35.

21. Protasov V.F. Ecology, health and protection of the environment in Russia. M .: Finance and statistics. 2000. - 672 p.

22. Turdiqulov E.0. Thinkers on environmental education. - Tashkent: UzPFITI, 2003. - 22 p..

23. Xankovskiy E.V. Ecological information in the design and implementation of municipal programs for the development of physical culture: author. diss ... kand.ped.nauk. - Chelyabinsk: 000 "Eykon", 2009. - 30 p.

24. Shchepetkina I.V. Ecological and legal education of students in the educational process of the university: author. Diss ... Candidate of Pedagogical Sciences. Yekaterinburg: Ural State Forestry University, 2012. - 30 p.

25. Chimitov Z.B. Ecological tourism as a factor of familiarizing people with the values of natural and cultural heritage: abstract of Ph.D. diss ... cand. cultural studies. - UlanUde: "Belig", 2006. - 30 p. 